\title{
The Influence of Internal Control, Leadership Style, and Teamwork to Information System Project Success
}

\author{
Anderes Gui ${ }^{1}$, Yudi Fernando ${ }^{3}$, Aditya Septiani Wiwoho ${ }^{2}$, Bambang Leo \\ Handoko ${ }^{2}$, and Hasnah Haron ${ }^{3}$ \\ ${ }^{1}$ Information Systems Department, School of Information Systems, Bina Nusantara University, \\ Jakarta, 11480, Indonesia \\ ${ }^{2}$ Accounting Department, Faculty of Economics and Communication, Bina Nusantara University, \\ Jakarta, 11480, Indonesia \\ ${ }^{3}$ Faculty of Industrial Management, Universiti Malaysia Pahang, Lebuhraya Tun Razak, 26300 \\ Gambang, Pahang, Malaysia
}

\section{Abstract}

The purpose of this research is to investigate the influence of internal control, leadership style, and teamwork on the success of the information technology projects. The method of data collection is done by studying literature, questionnaires, interviews, and direct

Corresponding Author:

Anderes Gui

anderesgui@binus.edu

Received: 5 August 2019

Accepted: 14 August 2019

Published: 18 August 2019

Publishing services provided by

Knowledge $\mathrm{E}$

(c) Anderes Gui et al. This article

is distributed under the terms of

the Creative Commons

Attribution License, which

permits unrestricted use and

redistribution provided that the

original author and source are

credited.

Selection and Peer-review under

the responsibility of the

FGIC2019 Conference

Committee. field observations. The research methodology used is quantitative method with the primary and secondary data source. Questionnaires were distributed to the project team, and 110 responses of employees at AIT Co. were received. Data were analyzed using IBM SPSS. Findings showed that internal control and teamwork have a significant influence on the success of the information technology projects, but leadership style not significant. It was found that internal control, leadership style, and teamwork simultaneously have a significant and positive influence on the information technology projects success by $80 \%$. The implication of this study is to increase successful project rate, the role of internal control is important to monitor from the earliest stage until project finished, and company needs to arrange program such as watch together, eat together or outing program. For future research is to expand the scope of the study, such as increasing the number of companies involved, with variations in other variables and can add control and moderating variables.

Keywords: internal control, leadership style, teamwork, information technology project success.

\section{G OPEN ACCESS}

\section{Introduction}

Nowadays, globalization is driving the development of technology; thus, Information Technology (IT) is more functional and vitally needed for a company which wants to remain sustainable in their business. According to Whitney and Daniels (2013), the evolvement of technology progress and global expansion has increased the number of 
technology projects. This is supported by Gomes and Romao (2016), which stated that the company had increased its investment in technology. Stoica and Brouse (2013) stated that project failure happens and no industry is immune from project failure. Information technology projects have been proven to be more vulnerable to risk and failure more than in other industries. According to Gartner (2011), the projections of global information technology spending have risen by $5.4 \%$ with figures reaching 3.4 trillion US dollars in 2010. Table 1 shows the CHAOS Summary Report from Standish Group, which turns out that information technology failure projects have shown a worrying trend since 2011.

TABLE 1: Successful Project from CHAOS Report by Standish Group.

\begin{tabular}{|l|l|l|l|l|l|l|}
\hline & 2011 & 2012 & 2013 & 2014 & 2015 \\
\hline Successful & $29 \%$ & $27 \%$ & $31 \%$ & $28 \%$ & $29 \%$ \\
\hline Challenged & $49 \%$ & $56 \%$ & $50 \%$ & $55 \%$ & $52 \%$ \\
\hline Failed & $22 \%$ & $17 \%$ & $19 \%$ & $17 \%$ & $19 \%$ \\
\hline
\end{tabular}

According to previous studies, (Atkinson, 1999; Shenhar, Levy \& Dvir, 1997; Jugdev and Muller, 2005; Thomas \& Fernandez, 2008; Collyer \& Warren, 2009, Gomes \& Romao, 2016) mentioned that the "iron triangle" or "triple constraint" can be used to measure the success of a project. Project success is measured based on the achievement of project costs, time, and quality. By considering these three factors, it will be easier to measure the success or failure of a project. To be clear, what is meant by failure in an information technology project is if there is a delay in the completion time, the target cost is exceeded, or the project is not following what has been agreed upon. In the management project itself, there are three important elements in project management. The first element is the internal control system of the project. Planning of the project is important to ensure all elements in project management are in accordance to plan. The second element is the project manager, who is the person responsible for planning, directing, and integrating the work effort of the members to achieve the project's objectives. The third element is the project team itself. The project team is a collection of people or team members from different functional areas working together with the aim of completing project work. Team members will have a project manager who will direct the project so that the three elements are interrelated and important. Based on these three elements, this study will examine whether internal control factor, leadership style, and teamwork have a relationship with the success of information technology projects. Previous studies have not examined all three factors in one study. 


\section{Literature Review}

Previous research conducted by Schendar, Tishler, Dvir, Lipovetsky, and Lecher (2002), Belout and Gauvreau (2004) shows the relationship between control and project success. Table 2 shows summarize these studies.

TABLE 2: Relationship of Internal Control and Success of Information Technology Projects.

Researcher
Schenhar, Tishler, Dvir,
Lipovetsky, Lecher
(2002)
Belout, Gauvreau
(2004)

\section{Research Result}

The sampling method used was purposive sampling. Questionnaires were distributed to 127 project manager in Israel. Data were analyzed using canonical correlation and eigenvector analysis. Findings show that there is a relationship between control and the success of the project.

This research aims to analyze the factors that influence project success. The sampling method used is Stratified Random Sampling.

Questionnaires were distributed to 212 project managers. Findings show internal control has an influence on the success of projects.

Previous studies related leadership style and project success by Thite (2000), Jiang (2014), Liphadzi, Aigbavboa, \& Thwala (2015), Aga (2016) and Aga, Noorderhaven, \& Vallejo (2016) show in Table 3 below:

TABLE 3: Relationship of Leadership Style and Information Technology Project Success.

\begin{tabular}{|c|c|}
\hline Researcher & Research Result \\
\hline Thite (2000) & $\begin{array}{l}\text { This research aims to identify successful leadership styles of information } \\
\text { technology managers. This study analyzes the transformational } \\
\text { leadership style (TLS) and its relationship to the success of projects. The } \\
\text { sampling method used is random sampling. The questionnaire was } \\
\text { distributed to } 111 \text { IT organizations in Australia. Findings show that there is } \\
\text { a relationship between TLS and ITPS. }\end{array}$ \\
\hline Jiang (2014) & $\begin{array}{l}\text { The research was conducted with a literature review of various sources of } \\
\text { project management journals, change management, and other books. It } \\
\text { can be summarized that leadership is rarely included in the success } \\
\text { factors of the project, but these factors can affect the performance of the } \\
\text { project directly and indirectly. The direct influence of leadership is that it } \\
\text { can increase the success of the project with the appropriate } \\
\text { competencies. }\end{array}$ \\
\hline $\begin{array}{l}\text { Liphadzi, Aigbavboa, } \\
\text { Thwala (2015) }\end{array}$ & $\begin{array}{l}\text { The aim of this research is to explore the relationship between different } \\
\text { leadership styles and the success of projects. Questionnaires were } \\
\text { distributed to } 150 \text { construction managers in South Africa. Findings show } \\
\text { the strong relationship between leadership style towards the success of } \\
\text { the project. }\end{array}$ \\
\hline Aga (2016) & $\begin{array}{l}\text { The sampling method used was purposive sampling. Questionnaires } \\
\text { were distributed to } 224 \text { development projects managers at NGOs in } \\
\text { Ethiopia. It was found that there is a relationship between transactional } \\
\text { leadership and the success of the project. }\end{array}$ \\
\hline $\begin{array}{l}\text { Aga, Noorderhaven, } \\
\text { dan Vallejo (2016) }\end{array}$ & $\begin{array}{l}\text { This research aims to determine the relationship between } \\
\text { transformational leadership style and the success of the project and also } \\
\text { examine whether team building will moderate the relationship. } \\
\text { Questionnaires were sent to } 431 \text { NGOs in Ethiopia. Findings show that } \\
\text { transformational leadership has a relationship with the success of the } \\
\text { project. }\end{array}$ \\
\hline
\end{tabular}


Previous studies related teamwork and project success by Hoegl and Gemuenden (2001), Yang, Huang \& Wu (2011), Cserhati, Szabo (2013), Lindsjorn, Sjoberg, Dingsoyr, Bergersen, \& Dybua (2016 Wu, Liu, Zhao, \& Zuo (2017) show in Table 4 below:

TABLE 4: Relationship on Team Work and Successful of Information Technology Project.

\begin{tabular}{|c|c|}
\hline Researcher & Research Result \\
\hline $\begin{array}{l}\text { Hoegl, Gemuenden } \\
\text { 2001) }\end{array}$ & $\begin{array}{l}\text { Questionnaires were distributed to } 575 \text { team members, team leaders, } \\
\text { and managers of software companies in Germany. Findings show that the } \\
\text { quality of teamwork has a strong relationship with the success of the } \\
\text { project. }\end{array}$ \\
\hline Yang, Huang, Wu (2011) & $\begin{array}{l}200 \text { questionnaires were distributed to the project managers of } \\
\text { construction companies in Taiwan. Findings show that leadership style } \\
\text { and teamwork have a positive relationship with the performance of } \\
\text { projects. }\end{array}$ \\
\hline serhati, Szabo (2013) & $\begin{array}{l}\text { Data collection is done by conducting interviews and distributing } \\
\text { questionnaires to event managers of selected companies in Europe. The } \\
\text { results of the study show that the relationship-oriented project success } \\
\text { factors, such as communication, collaboration, and project leadership, } \\
\text { play an important role in carrying out organizational projects. }\end{array}$ \\
\hline $\begin{array}{l}\text { Lindsjorn, Sjoberg, } \\
\text { Dingsoyr, Bergersen, } \\
\text { Dybua (2016) }\end{array}$ & $\begin{array}{l}\text { This research was conducted to investigate the influence of the quality of } \\
\text { collaboration on team performance, learning, and job satisfaction on the } \\
\text { team of software developers in Norwegian using the agile method. } \\
\text { Questionnaires were distributed to } 477 \text { respondents from } 26 \text { companies } \\
\text { and analyzed using SEM. The result shows that teamwork quality has a } \\
\text { relationship with the success of the project. The quality of teamwork is a } \\
\text { major factor in improving team performance especially for software } \\
\text { development teams that use the agile method. }\end{array}$ \\
\hline $\begin{array}{l}\text { Wu, Liu, Zhao, Zuo } \\
\text { (2017) }\end{array}$ & $\begin{array}{l}\text { Questionnaires were distributed to construction project managers in } \\
\text { Shanghai, Jiangsu and Zhejiang provinces in China. Data analysis was } \\
\text { performed using SEM (Structural Equation Modeling). Findings show that } \\
\text { desire to communicate and formal communication has a positive } \\
\text { relationship with the success of the project, while informal } \\
\text { communication does not affect the success of the project. }\end{array}$ \\
\hline
\end{tabular}

\section{Methodology}

In this research, there are three independent variables, which are internal control, leadership style, and teamwork, and the dependent variable are the success of an information technology project. The population in this research are 150 employees of AIT Co. that are directly involved and is in the information technology application development team. The sampling technique used is purposive sampling technique. Unit of analysis comprise of employees of AIT Co., is in the information technology application development team and has a role as a project manager, business analyst, system analyst, developer, tester, and quality assurance. Using the Slovin formula, a minimum sample of 110 respondents for this study was collected in January 2018. Quantitative research is conducted. The research instrument is a questionnaire. IBM SPSS will be used to test the hypotheses. 


\section{Results}

\subsection{Hypothesis}

There are four hypotheses formulated in this study based on the previous literature. The discussion of each hypothesis will be described as follows:

a. Hypothesis $1(\mathrm{H} 1)$

The purpose of hypothesis 1 is to find out whether there is an influence between internal controls on the successful of information technology projects. $\mathrm{H} 1$ states that internal control has a significant and positive influence on the success of information technology projects.

b. Hypothesis $2(\mathrm{H} 2)$

The purpose of hypothesis 2 is to find out whether there is an influence between leadership styles on the successful of information technology projects. $\mathrm{H} 2$ states that leadership style has a significant and positive influence on the success of information technology projects.

c. Hypothesis $3(\mathrm{H} 3)$

The purpose of hypothesis 3 is to find out whether there is an influence between teamwork on the success of information technology projects. H3 states that teamwork has a significant and positive influence on the success of information technology projects.

d. Hypothesis $4(\mathrm{H} 4)$

The purpose of hypothesis 4 is to find out whether there is an influence between internal control, leadership style, and teamwork on the success of information technology projects. H4 states that internal control, leadership style, and teamwork has a significant and positive influence on the success of information technology projects.

\subsection{Data Quality Test}

This quality test is done by testing the validity and reliability of the data collected. If there are items that are invalid and reliable, they will be excluded from the question items. The results of the validity test are all items asked in the questionnaire are valid because for all variables, namely internal control, leadership style, teamwork, and success of information technology projects have a calculated $r$ which is higher than $r$ table. Furthermore, the results of reliability tests are all question items declared reliable because all variables ranging from internal control, leadership style, teamwork, 
and success of information technology projects have a Cronbach's Alpha value greater than 0.6. Then from the results of the data quality test can be used to disseminate questionnaires to the object of research to be studied.

\subsection{Classic assumption test}

\section{TABLE 5: Classical Assumption Test Results.}

\begin{tabular}{l|l}
$\begin{array}{l}\text { Testing of Classical Assumption } \\
\text { Test }\end{array}$ & Results \\
\hline Normality & The regression model is normally distributed \\
\hline Heteroscedasticity & There is no heteroscedasticity in the regression model \\
\hline $\begin{array}{l}\text { Autocorrelation } \\
\text { Multicollinearity }\end{array}$ & There is no autocorrelation in the regression model \\
\hline
\end{tabular}

All the assumptions have been met.

\subsection{Correlation Analysis}

In this correlation test, it aims to determine the closeness of the relationship between internal control on the success of information technology projects, closeness between leadership style on the success of information technology projects, and the closeness of the relationship between work team on the success of information technology projects. The following is a summary of the results of the correlation test obtained from data processing using the SPSS program.

TABLE 6: Results of the Correlation Testing Summary.
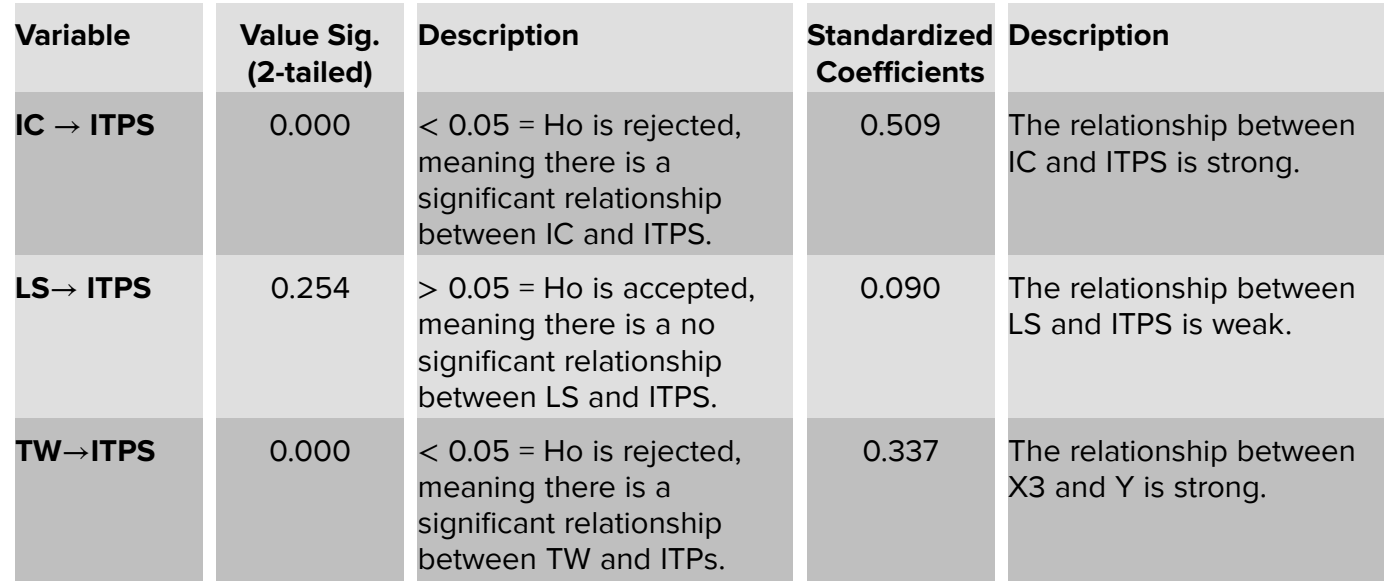

From Table 6, it can be seen that there is a strong and direct influence on the success of the Information Technology Project. Furthermore, the Leadership Style has 
an insignificant, weak relationship and direct influence on the success of the Information Technology Project. Team Work has a significant and strong relationship and a direct influence on the Information Technology Project Success.

\subsubsection{Multiple Regression Analysis}

Multiple regression testing is done by regressing all the independent variables on the dependent variable. The independent variables included in this research are three, those are internal control, leadership style, and teamwork, while the dependent variable is the success of an information technology project whose details will be explained as follows. Table 4 shows the test of the internal control Summary Model, leadership style, and teamwork, on the success of information technology projects using the IBM SPSS 20.0 program, so the test results are found as follows:

TABLE 7: Summary of Internal Control Models, Leadership Style, and Team Work on the Success of Information Technology Projects.

\begin{tabular}{|c|c|c|c|c|}
\hline Model & $\mathrm{R}$ & R Square & $\begin{array}{l}\text { Adjusted R } \\
\text { Square }\end{array}$ & $\begin{array}{l}\text { Std. Error of } \\
\text { the Estimate }\end{array}$ \\
\hline 1 & $.896^{a}$ & .803 & .797 & .823 \\
\hline
\end{tabular}

In the Model Summary in Table 7, it shows that there is a relation coefficient column $(R)$ and a coefficient of determination ( $R$ Square). In column $R$, there is a number 0.896 , which indicates that the relationship is very strong and in the same direction because the value is positive. Also, in the R Square column, there is a number 0.803 so that it can be concluded that the variables of internal control, leadership style, and teamwork affect the success of information technology projects by $80 \%$ while the remaining $20 \%$ vitally by other factors outside of the variables studied. Next is the $F$ test or ANOVA test to compare the significance level set for the study with the probability value of the research results.

TABLE 8: Output of ANOVA Internal Control, Leadership Style, and Team Work on the Success of Information Technology Projects.

ANOVA $^{2}$

\begin{tabular}{|ll|l|l|l|l|l|}
\hline \multicolumn{2}{|l|}{ Model } & Sum of Squares & df & Mean Square & $\mathrm{F}$ & Sig. \\
\hline \multirow{4}{*}{1} & Regression & 292.178 & 3 & 97.393 & 143.740 & $.000^{\circ}$ \\
& Residual & 71.822 & 106 & .678 & & \\
& Total & 364.000 & 109 & & & \\
\hline
\end{tabular}

a. Dependent V ariable: ITPS

b. Predictors: (Constant), IC, LS, TW 
Table 9 shows that Internal Control and Teamwork has a significant and positive influence on information technology project success, and leadership style insignificant.

TABLE 9: Regression Equations for Internal Control, Leadership Style, and Team Work on the Success of Information Technology Projects.

\begin{tabular}{|c|c|c|c|c|c|c|}
\hline \multicolumn{7}{|c|}{ Coefficients $^{a}$} \\
\hline \multicolumn{2}{|c|}{ Model } & \multicolumn{2}{|c|}{ Unstandardized Coefficients } & \multirow{2}{*}{$\begin{array}{c}\text { Standardized } \\
\text { Coefficients } \\
\text { Beta }\end{array}$} & \multirow[t]{2}{*}{ T } & \multirow[t]{2}{*}{ Sig. } \\
\hline & & B & Std. Error & & & \\
\hline \multirow[t]{4}{*}{1} & (Constant) & 1.056 & .668 & & 1.580 & .117 \\
\hline & IC & .416 & .074 & .509 & 5.583 & .000 \\
\hline & LS & .046 & .041 & .090 & 1.146 & .254 \\
\hline & TW & .196 & .064 & .337 & 3.071 & .003 \\
\hline
\end{tabular}

It can be seen from Table 9 that only internal control and teamwork is significant and positively related to information technology project success. Leadership style is not significant and positively related to Information Technology Project Success.

The following is an overview of the frame of mind that includes the independent variables and the dependent variable examined in this study, along with the percentage of the influence of each independent variable on the dependent variable.

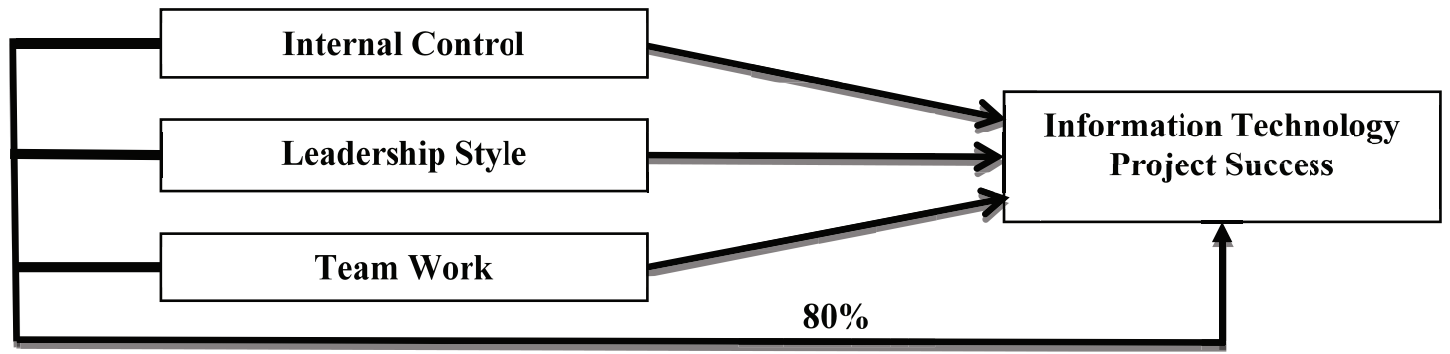

\section{Discussion}

It can be concluded that internal control and teamwork have a significant and positive influence on the success of information technology projects. However, leadership style was not found to be significant because the company using KPI to measure the performance of each member team.

\section{Conclusion and Implications}

Internal control of information technology projects is the most significant influential factor. In accordance with the research conducted by Pimchangthong and Boonjing 
(2017), the company needs to establish internal control in guarding the development of information technology projects. Teamwork also has a significant effect on the success of information technology projects, and this is in line with the research conducted by Yang, Huang, and Wu (2011). To improve teamwork, companies need to do outing programs, watch together, and go together so that a sense of togetherness is created between managers and project members. For future researchers who are interested in the topic of internal control, leadership style, and teamwork towards the success of information technology projects is to expand the object of research by increasing the number of companies involved, with variations in other variables and can add control and moderating variables.

\section{References}

[1] Aga, D. A. (2016). Transactional leadership and project success: the moderating role of goal clarity. Procedia Computer Science, 100, 517-525.

[2] Aga, D., \& N. Noorderhaven, B. V. (2016). Transformational leadership and project success: The mediating Transformational leadership and project success: The mediating. International Journal of Project Management, 34, 806-818.

[3] Atkinson, R. (1999). Project management: cost, time and quality, two best guesses and a phenomenon, its time to accept other success criteria. International, 17, 337342.

[4] Belout, A., \& Gauvreau, C. (2004). Factors influencing project success: the impact of human resource management. International Journal of Project Management, 22, $1-11$.

[5] Collyer, S., \& Warren, C. (2009). Project management approaches for dynamic environments. International Journal of Project Management, 27, 355-364.

[6] Cserhati, G., \& Szabo, L. (2013). The relationship between success criteria and success factors in organisational event projects. International Journal of Project Management, 1-12.

[7] Gartner. (2011). Gartner raises global IT spend f'cast. Reuters.

[8] Gomes, J., \& Romao, M. (2016). Improving project success: A case study using benefits and project management. Procedia Computer Science, 100, 489 - 497.

[9] Hoegl, M., \& Gemuenden, H. G. (2001). Teamwork Quality and the Success of Innovative Projects: A Theoretical Concept and Empirical Evidence. Organization Science, 12 (4), 435-449. 
[10] Jiang, J. (2014). The Study of the Relationship between Leadership Style and Project Success. American Journal of Trade and Policy, 1, 51-55.

[11] Jugdev, K., \& Muller, R. (2005). A retrospective look at our evolving understanding of project success. Project Management Journal, 36, 19-31.

[12] Lindsjorn, Y., Sjoberg, D. I., Dingsoyr, T., Bergersen, G. R., \& Dybua, T. (2016). Teamwork Quality and Project Success in Software Development: A Survey of Agile Development Teams. The Journal of Systems \& Software, 1-26.

[13] Liphadzi, M., Aigbavboa, C., \& Thwala, W. (2015). Relationship between leadership styles and project success in the South Africa construction industry. Procedia Engineering, 2015, $284-290$.

[14] Pimchangthonga, D., \& Boonjing, V. (2017). Effects of Risk Management Practice on the Success of IT Project. Procedia Engineering, 182, $579-586$.

[15] Shenhar, A. J., Levy, O., \& Dvir, D. (1997). Mapping the dimensions of project success. Project Management Journal, 28, 5-9.

[16] Shenhar, A. J., Tishler, A., Dvir, D., Lipovetsky, S., \& Lecher, T. (2002). Refining the search for project success factors: a multivariate, typological approach. $R \&$ D Management, 32 (2), 111-126.

[17] Standish Group. (2009). CHAOS Summary Report.

[18] Stoica, R., \& Brouse, P. (2013). IT project failure: A proposed four-phased adaptive multi-method approach. Procedia Computer Science, 16, 728 - 736.

[19] Thite, M. (2000). Leadership styles in information technology projects. International Journal of Project Management, 18, 235-241.

[20] Thomas, G., \& Fernandéz, W. (2008). Sucess in IT Projects: A matter of definition? International Journal of Project Management, 26, 733-742.

[21] Whitney, K. M., \& Daniels, C. B. (2013). The Root Cause of Failure in Complex IT Projects:Complexity Itself. Procedia Computer Science, 20, 325-330.

[22] Wu, G., Liu, C., Zhao, X., \& Zuo, J. (2017). Investigating the relationship between communication-conflict interaction and project success among construction project teams. International Journal of Project Management, 35, 1466-1482.

[23] Yang, L.-R., Huang, C.-F., \& Wu, K.-S. (2011). The association among project manager's leadership style, teamwork and project success. International Journal of Project Management, 29, 258-267. 